\author{
Conradie, Ernst $\mathrm{M}^{1}$ \\ University of the Western Cape
}

\title{
All theology is natural theology: The hermeneutic necessity of natural theology?
}

\begin{abstract}
This article first offers a brief overview of the history of what is understood under "natural theology". The contrast between the Barthian critique against natural theology and the dangers of repudiating natural theology as stressed within the context of contemporary discourse on science and theology is highlighted. In response, the author offers a constructive proposal in which the hermeneutic necessity of natural theology is affirmed. This follows from a notion of that which is "natural" which includes human constructs (also ideas). In this sense all theology is by definition natural theology. However, the Barthian critique against natural theology may still be appropriate as a selection of those signs that can express the inexpressible with relative adequacy.
\end{abstract}

\section{INTRODUCTION}

The term natural theology has been used in rather different ways, also within the South African context. In this contribution I will add to this confusion by offering a constructive thesis suggesting that "all theology is natural theology" - at least in one sense of the word. My aim is twofold, namely to contribute to reformed discourse on natural theology but also to bring insights from Calvin's Institutes into play in the context of contemporary science and theology discourse on natural theology.

This aim has to be understood from the observation that these discourses are scarcely in serious conversation with each other. In the context of reformed theology, also from within the South African context, debates on natural theology over the last 100 years or so have become largely focussed on the Barthian critique against natural theology and the aftermath of the Barth-Brunner controversy. This has helped to highlight the destructive potential of an uncritical form of natural theology - as is amply illustrated in the context of Nazi Germany and apartheid South Africa.

One cannot help but to notice that there is a completely different tone and set of assumptions at play in science and theology discourse on natural theology. It is also remarkable how little awareness of the dangers of natural theology, that Barth and others fulminated against, there remains in contemporary science and theology discourse. In fact, the dangers of repudiating natural theology (especially in Protestant theology) are highlighted. As Elizabeth Johnson (2000:9) observes: "However, the trajectory of Protestant theology shows increasing repudiation of anything remotely smacking of Catholic natural theology and its association with works' righteousness. Human nature in its fallenness is depraved; nature as a whole can only refer to fallen creation, which is empty of God's presence and in need of God's sovereign act of salvation given only in Christ. Theology's vision thus stays focused on humanity where the all-important saving

1 Prof EM Conradie, Professor, Department of Religion and Theology, University of the Western Cape, Private Bag X17, Bellville 7535. E-mail: econradie@uwc.ac.za. 
action of God takes place." My intention here is not to critique any sense of complacency on the dangers of natural theology, but to suggest a route, which may make conversation possible.

\section{THE DIVERGING NOTIONS OF NATURAL THEOLOGY}

It is important to situate this contribution within the history of discourse on natural theology in the Christian tradition in order to make meaningful conversation possible. I offer a few brief comments in this regard:

As Pannenberg (1991:73-82) observes, natural theology emerged from within the context of Stoicism where the focus was on reflection on the nature of God. Here the need was recognised to assess the many provincial claims to knowledge of God in mythic and political (pre-Christian) forms of religion. What claims can be taken seriously for a philosophically plausible notion of God? In this context a criterion was established that was later also applied to the message of Christianity. Christian theology had to explain why its confession of God was not restricted to the tribal God of the Jews but that the triune God was indeed the God of all peoples and the creator of everything that is. This criterion was accepted by early Christian apologists and by the church fathers. It was therefore also necessary to explain how the Christian notion of God related to the God of the philosophers. Since the existence and plausibility of belief in God was assumed, natural theology entailed reflection on the nature of God (on the basis of philosophical reflection). For many early and medieval theologians it was clear that, at least at a conceptual level, there are features that the Christian faith in the triune God had in common with the god of the philosophers. For example, the absolute transcendence and the unity of God were commonly accepted but not the threeness of faith in God as Father, Son and Holy Spirit.

A different notion of natural theology emerged when the question was raised how such claims to knowledge of God was possible in the first place. On what basis can such claims be made? The existence of a divine being was still taken for granted but it became necessary to explain where such claims come from and how they can be supported and defended. It is within this context that the famous proofs for God's existence can be situated. However, it should be noted that the focus here remained on the need to clarify the common ground between the claims of the Christian faith and the knowledge of God that may be found elsewhere. This was not a debate on the question whether God exist but on the nature and characteristics of God.

The advent of modernity changed the assumptions of such discourse on natural theology. It became increasingly important to demonstrate the plausibility of any claim to knowledge of God on the basis of the two pillars of rationality and empirical evidence. I will deal with the first of these briefly. ${ }^{2}$

The rationality of Christian and other claims now had to be defended on the basis of an understanding of human reason and human subjectivity. The focus here was on the limits of human reason and the ways in which any knowledge is structured by human rationality (Kant). Given the limits of human knowledge it became less clear how any claims to knowledge of God could be made. Here natural theology focused on reflection on human nature, therefore no longer on the nature of God. The question now became: What kind of being is it that has a

2 See McGrath (2009:2-3) with reference to James Barr's description of natural theology (in his Gifford lectures of 1991): “[T]raditionally, 'natural theology' has commonly meant something like this: that 'by nature', that is, just by being human beings, men and women have a certain degree of knowledge of God and awareness of him, or at least a capacity for such awareness; and this knowledge or awareness exists anterior to the special revelation of God made through Jesus Christ, through the Church, through the Bible." Since 1750 an Enlightenment notion of natural theology dominated discussions, namely "a defense of the existence of God on the basis of those criteria that the Enlightenment regarded as authoritative and reliable - namely, reason and the natural order." 
consciousness of a divine being? Our shifting understanding(s) of human rationality became the criterion to judge any understanding of God - which also indicate the roots of atheism or agnosticism. Liberal Christianity accepted the task of defending the plausibility of the Christian faith on the basis of this criterion. As we will see below, later forms of natural theology not only inquired about the transcendental conditions for the possibility of such knowledge, but also investigated the underlying role of brain functions in the context of the evolution of the human species.

The second of these pillars is especially important for my argument. The question emerged how Christian and other claims relate to the knowledge that we have of the world around us. The roots of empiricism are of course complex but one can certainly trace that back to Roger Bacon and the early Franciscan tradition. Here a distinction was made between the so-called "book of nature" and the "book of Scripture". Again, the question was how these two sources of our knowledge of God are related. What do they have in common? In Protestant discourse a similar distinction was later made between God's "general revelation" (in the beauty and order of nature, through human reason and amongst other religious traditions) and God's "special revelation" (in the history of Israel, in Jesus Christ and the work of the Holy Spirit in the early church). The question that was addressed in this form of natural theology remained how such knowledge of nature ("natural philosophy") is related to the (Christian) faith in God. Natural theology is thus understood as theological reflection on bio-physical nature.

It is not necessary to trace the history of reflection on this question in detail. It may suffice to indicate a range of answers that may be given to this question. For some contemplation of nature (including human nature) provides the necessary foundation upon which any further claims about knowledge of the transcendent can be made. In order to assure the firmness of such a foundation, it is best developed into a philosophically coherent system of knowledge (as in Thomist metaphysics). For others the knowledge gained from the study of nature actually provides proofs for God's existence. Typically such arguments are based on the "design" that is evident in nature. Here one may consider versions of the cosmological proof for God, William Paley's form of natural theology, Gideon Joubert's award-winning book Die groot gedagte or contemporary discourse on intelligent design (ranging from the notion of a "cosmic blueprint" (Paul Davies) to a vaguer sense of directionality in evolutionary history). Yet others do not find in such evidence any proofs, but they do look for a "new consonance" (Ted Peters and others), for confirmation of the plausibility of beliefs that they hold on other grounds (perhaps a form of fides quaerens intellectum). Accordingly, such evidence cannot lead to faith in the triune God but can strengthen such faith.

More recently, various exponents of the so-called new-style natural theology focus on the incompleteness of scientific knowledge of physical (non-human) nature. They argue that any knowledge is necessarily interpreted and that the so-called "laws of nature" remain incomplete - in two senses, namely that our knowledge of the laws remains provisional but also that physical reality is underdetermined by such laws, allowing for contingency and random variation. Scientific knowledge is integrated in scientific paradigms and in larger interpretative frameworks, deeply influenced by cosmological and indeed by metaphysical assumptions. Scholars such as Ian Barbour, Arthur Peacocke and George Ellis suggest that this offers a new place for the role of ethics and religion in the "hierarchy of sciences". The quest for transcendence is rooted in the very nature of any disciplined inquiry on nature. New-style natural theology is therefore no longer aimed at gaining knowledge of God from the so-called "book of nature" (alone). Instead, it seeks to portray Christian theism as a plausible and intellectually satisfying understanding of the sum-total of scientific knowledge (including the human sciences and the arts). Theological reflection may therefore provide resources for a single coherent account of reality as a whole, 
a new metaphysics, a form of discernment through the eyes of the Christian faith (see Barrett 2009:179f). In his recent Gifford lectures Alister McGrath (2009, see also 2008) suggests that the Christian faith in the triune God may offer such a plausible interpretation. This approach to natural theology is perhaps best captured by CS Lewis's famous remark also quoted by McGrath: "I believe in Christianity as I believe that the sun has risen, not only because I see it, but because by it I see everything else."

\section{NATURAL THEOLOGY: A CONSTRUCTIVE THESIS}

The notion of natural theology as disciplined reflection on physical nature continues to juxtapose two sources for the knowledge of God (or two "means" as Article II of the Belgic Confession has it): the particularity of the Christian faith based on "special revelation" and what the Christian faith may have in common with other forms of knowledge and other religious traditions (based on "general revelation"). Karl Barth's vehement critique against natural theology has to be understood in this light. It rejected any form of theology that claims to interpret divine revelation where the subject matter differs fundamentally from the revelation in Jesus Christ and where the method employed differs equally from an exposition of Scripture (Barth 2002:74-75). It also rejected any external criterion for the adequacy (or plausibility) of the Christian faith, especially on the basis of the limits to human nature and human knowing. This critique against natural theology thus suggests that knowledge of the triune God has little if anything to do with truth claims in other disciplines. There is no need to find common ground or to explore commonalities since this would typically lead to the accommodation of the Christian faith to the dominant way of thinking at a particular time.

As Pannenberg (1991:69) astutely observes, this may come at the cost of the intelligibility of what Christians have to say about God. Jewish-Christian notions of God emerged on the basis of earlier concepts of God and cannot be understood without reference to these. Questions on the nature of God and therefore on the relationship between the Christian faith in the triune God and other notions of God therefore has to be addressed. This problem emerges again and again - in bible translation, in missiological discourse, in reflection on the relation between the Christian faith and African Traditional Religion and in contemporary debates on natural theology.

In this contribution I will question the distinction that is made between these two sources for the knowledge of God. I will argue that what is called "special revelation" in the reformed tradition forms part of the world of nature. The book of Scripture forms part of the book of nature. In this sense of the word all theology is natural theology. The constructive thesis that is offered here, going against the grain of much of reformed theology, is that reformed debates on natural theology all too often fail to come to terms with the hermeneutical insight that all the categories that we employ to speak of God and to God come from the world of "nature". ${ }^{3}$ The strength of the reformed critique against natural theology (to be illustrated through a rereading of Calvin's Institutes) may then be understood as a qualitative judgement on the actual content of such knowledge, on where such knowledge may best be found.

It may be helpful to draw an analogy with debates on contextual theology in the South African context in the 1980s. Those who used "contextual theology" as a self-description gradually had to recognise that all forms of theological reflection are contextual. Indeed apartheid theology may be regarded as one of the best, if extremely narrow, examples of contextual theology.

3 This would also apply to Barth's vehement critique of natural theology. To say that all theology is natural theology is, of course, not to adopt Barth's own definition of natural theology as described above. This hermeneutical approach to natural theology may also be contrasted with the brave attempts to explore a Barthian version of natural theology by Torrance (1980) and Hauerwas (2001). 
Contextual theology therefore could not by itself be used to introduce a distinction between emancipatory and oppressive forms of theology. ${ }^{4}$ Yet, such a qualitative distinction remained necessary in order to guard against oppression, idolatry and indeed heresy.

In my view the hermeneutic inevitability of a form of natural theology cannot be denied. Intellectual history since the advent of modernity has made it abundantly clear that the only access which we have to God's revelation is from within our own historical epoch (the historical turn), through the categories of human reason (the turn to the subject), a particular preunderstanding (the hermeneutical turn), language (the linguistic turn), culture (the sociological turn) and our position in society in terms of gender, race, class and education. The categories, which we use to talk about God, come from below, not directly from above (Harry Kuitert). God's revelation necessarily has a "natural", an earthly character. A purist position on natural theology is therefore (contra Barth) scarcely tenable. As Jürgen Moltmann puts it, natural theology is the active presupposition of all Christian theology. ${ }^{5}$

Whenever we use categories such as "revelation" or "God's word", we do that at best as recipients and witnesses to insights that we have gathered within our own context. Instead of denying or hiding the use of categories derived from outside the Christian tradition, it is better to articulate the categories which we do employ as honestly as possible so that they can be open to public scrutiny. A failure to do so may lead to an authoritarian theology, which equates our words about God (from below) too easily with God's own word (as it were "from above"). Then we may be tempted to speak on God's behalf and with God's authority almost as if we were God.

There is also a second sense in which theological hermeneutics assumes some form of natural theology. Any theology that seeks to discern the "signs of the time" would need to grapple with issues of contemporary culture, art and science. This is necessary to understand the significance of the gospel, but such contextual considerations also shape one's understanding of the gospel itself. In an essay on preaching on the reign of God reformed theologian Arnold van Ruler makes this point forcefully. He says: "In actual fact the church of course always utilises such sources. Without natural theology the church cannot take any step into the world and cannot say a word over the things of the world, which is God's world. One will have to exercise extreme caution with such natural theology. That is obvious ... In any case, in my view one would also have to guard against the overvaluing of special revelation that is nowadays common. Without the Word of God I would not know how to live my life as sacrifice acceptable to God. But neither without reason, without the historical process or without science. The proclamation of God's reign is therefore not merely aggression towards heathendom but also synthesis with heathendom" (Van Ruler [1957] in 1978:51-22, my translation). In an essay on "the necessity of a trinitarian theology", Van Ruler (1978:23) reiterates this point: "Without some natural theology - if only

4 See especially the various contributions to the Festschrift for Albert Nolan (Speckman \& Kaufmann 2001).

5 Moltmann (2000:68) explains the notion of an "active presupposition" in this way: "If we understand natural theology as the forecourt to the temple, which would not exist without the temple itself, this does not mean that we have given up its truth, retreating to revealed theology. For an active presupposition of this kind is essential for revealed theology if it is to be theo-logy, and hence aims to present its historical modality as universal. The God of Israel is the creator of heaven and earth, not a tribal God of the Israelites." Moltmann contrasts this view of natural theology with the notions that natural theology is the eschatological goal of Christian theology (when ecclesiastical faith will give rise to the universal religion of modernity based on rationality and human dignity) and that Christian theology itself is the true natural theology. The latter view is similar to the notion of new-style natural theology referred to above, except that Moltmann resists the abstraction of an overly generalised theology in order to address the political concerns of a theology of the earth - in terms of human rights, multi-faith co-existence and ecological destruction. 
in the form of natural knowledge regarding the nature of worldly affairs - no church can exist. But it would be all too meagre to have nothing more than just a bit of natural theology. What rationality, history, human existence, the state and art entail, one would know, theologically, only on the basis of a fully developed trinitarian understanding" (my translation). For Van Ruler, such knowledge can only be understood pneumatologically, not in the first place christologically.

It should be noted that "nature" and "natural theology" is used here primarily as a hermeneutical category. We have access to the world around us and to God's revelation only on the basis of that which is natural - which includes the history of nature, the history of life on earth, human histories, human culture and those aspects of human life that are invisible and may therefore appear to be immaterial, but that are fully dependant on material brain functions (thought, language or love).

\section{NATURAL THEOLOGY AND THE NOTION OF “NATURE”}

Although it is possible to distinguish humanity from non-human nature, such a distinction is at best tenuous. It is a truism, often underplayed, that human beings simply form part of that which is natural. The reduction of "nature" to non-human nature can only lead to a further alienation of human beings from the rest of nature. It is such alienation that has prompted much of current ecotheology. Larry Rasmussen (1996:75-89), for example, refers to the "apartheid habit" of distinguishing between humanity and non-human nature, leaving the impression that we are an ecologically segregated species - that we are somehow separate, hence "apart" from the ecosystems in which we live. Rasmussen adds that the same "apartheid habit" is also manifested in the "great divorce" of nature from (human) history and the distinction between the natural and the human sciences so deeply embedded in academia. Instead, the history of humanity should be regarded as a mere episode in the larger history of the cosmos itself and of life in (not on) this planet. ${ }^{6}$

This implies that any language, all forms of theological reflection and any God-talk are derived from that which is natural. Theological discourse is an expression of human consciousness. As Thomas Berry (1988:195) would evocatively add: "The human is less a being on earth or in the universe than a dimension of the earth and indeed the universe itself" and "the human might be identified as that being in which the universe celebrates itself and its numinous origins in a special mode of conscious self-awareness" (1999:19).

Once this sense of rootedness is granted, one may, of course, encourage a rich differentiation of various aspects within that which is natural, perhaps on the basis of evolutionary theories of emergence. Murray Bookchin (1988), for example, distinguishes between "first nature" (the non-human natural world) and "second nature" which includes aspects of human evolution such as rationality, language, communication, culture and the economy. He adds that natural evolution has left humans not only with the ability but also with the necessity to intervene in "first nature". Such adaptations of "first nature" may be destructive but may also enhance biotic diversity and diminish suffering (see also Desjardin 2006:234f). ${ }^{7}$

6 The reformed ecotheologian Steven Bouma-Prediger notes five different reasons for rejecting such a dualism of nature and history: 1) The natural world is historical in its own right; 2) The natural world is deeply affected by human agency; 3) As corporeal agents humans are embedded in nature; 4) This dualism has led to disastrous consequences since it has been used to sanction various forms of exploitation; 5) It conflicts with the biblical notion of a single, all-embracing covenant with God. See Bouma-Prediger 1995:271, with reference to Rosemary Ruether's views in this regard.

7 On this basis I would admit that the category of "nature' tends to become all-inclusive. This is in my view necessary to stress in order to preclude the dualism and alienation that emerge whenever that which is human is distinguished from the rest of nature. The only category that would be un-"natural" (not to 
It is important to distinguish such a hermeneutical notion of "natural theology" from creation theology or a theology of nature. The term "creation" (either as creatio or as creatura) deals with questions of origin and creation theology explores the content and significance of the Christian confession in this regard. There is certainly a need for a "theology of nature", typically understood as theological reflection on non-human nature from the perspective of the Christian faith. As Clingerman (2009) argues, this requires another form of hermeneutics, namely one that recognises that our experience of nature is mediated by language and that reading nature as a rich text (the "book" of nature) may therefore be appropriate in order to capture its revelatory potential, if not a reference to its Author. Remarkably, it is a text in which the reader finds herself incorporated as a character in the text (2009:82). In such theological reflection on non-human nature it is crucial to remind ourselves that what we know as "nature" is always already the product not only of God's acts of creation (creatio) or of human distortion, but also of God's acts of providence, salvation and the formation of the church. From the perspective of the Christian faith no scientific experiment with regard to nature has ever been conducted where such nature is not influenced by God's work. Indeed, "nature" is necessarily interpreted; it is not self-evident or (in another sense) "purely natural".

\section{CONCLUSION}

My concern here it not to show how Christianity may offer an interpretative framework to understand nature (as in new-style natural theology), but to reflect on how Christian convictions emerged in the first place, namely on the basis of sensory perceptions. My argument is that all theological reflection may be regarded as natural theology in the sense that we inevitably use categories (vocabularies) derived from the world around us (in this sense from "nature"), for better or for worse. ${ }^{8}$ We use that in being recipients of and witnesses to what we would afterwards call "God's revelation", in forming any apprehension of God, in reading the Bible, and in understanding the significance of the gospel for our culture. Of course, such theological reflection stands in need of correction, as the Barthian critique of natural theology amply illustrates. However, it is a hermeneutical mistake to explain the need for such a critique in terms of the different sources used in theological reflection. Again, a purist critique against natural theology is undermined by the recognition that humans, human words and thoughts (including ethical notions of how the world should be, our images and concepts of God and the biblical narratives), form part of "nature".

\section{BIBLIOGRAPHY}

Barrett, P 2009. Seeing human personhood through science-religion-arts-ethics: An exercise in newstyle natural theology. In: Du Toit, CW (ed): The evolutionary roots of religion: Cultivate, mutate or eliminate? Pretoria: Unisa Press.

Barth, K 2002 [1946]. No! An answer to Emil Brunner. In: Natural theology, 67-128. Eugene: Wipf \& Stock.

Berry, T 1988. The dream of the earth. San Francisco: Sierra Club Books.

Berry, T 1999. The great work: Our way into the future. New York: Bell Tower.

Bookchin, M 1988. Social ecology versus Deep Ecology. Socialist Review 18:1-28.

mention God) would be human sin if understood as something that does not exist by itself but only as the privation of the good (privatio boni).

8 See also Von Balthasar's insistence that the concept of analogy (and some form of similarity) is indeed unavoidable: "For if we re-cognize God, this must mean that we see God using our prior views, concepts and words; thus we see God not as something totally Other. But in and with these means of images, concepts and words (the only ones we have), we truly do see God" (quoted in Hauerwas 2001:185). 
Bouma-Prediger, S 1995. The greening of theology: The ecological models of Rosemary Radford Ruether, Joseph Sittler, and Jürgen Moltmann. Atlanta: Scholars Press.

Clingerman, F 2009. Reading the book of nature: A hermeneutical account for philosophical theology. Worldviews 13, 72-91.

Desjardin, J 2006. Environmental ethics: An introduction to environmental philosophy. Toronto: Thompson Wadsworth.

Hauerwas, S 2001. With the grain of the universe. Grand Rapids: Brazos Press.

Johnson, EA 2000. Losing and finding creation in the Christian tradition. In: Hessel, DT \& Ruether, RR (eds): Christianity and ecology. Seeking the well-being of earth and humans, 3-22. Cambridge: Harvard University Press.

McGrath, AE 2008. The open secret: A new vision for natural theology. Oxford: Blackwell.

McGrath, AE 2009. A Fine-Tuned Universe: The Quest for God in Science and Theology. Louisville: Westminster John Knox Press.

Moltmann, J 2000. Experiences in theology: Ways and forms of Christian theology. Minneapolis: Fortress Press.

Pannenberg, W 1991. Systematic Theology Volume 1. Grand Rapids: WB Eerdmans.

Rasmussen, LL 1996. Earth community, earth ethics. Maryknoll: Orbis Books.

Speckman, MT \& Kaufmann, LT 2001. Towards an agenda for contextual theology. Pietermaritzburg: Cluster Publications.

Torrance, TF 1980. The transformation of natural theology. In: The ground and grammar of theology, 75108. Charlottesville: University Press of Virginia.

Van Ruler, AA 1978. Verwachting en voltooiing: Een bundel theologische opstellen en voordrachten. Nijkerk: Callenbach.

\section{KEY WORDS}

Hermeneutics

Natural theology

Nature

Theology of nature

\section{TREFWOORDE}

Hermeneutiek

Natuur

Natuurlike teologie

Teologie van die natuur 